\title{
Efektifitas Belimbing Manis (Averrhoa Carambola Linn) sebagai Anti Hipertensi pada Pasien Hipertensi di Puskesmas Metro Pusat, Kota Metro
}

\author{
Ari Khusuma $^{1^{*}}$, Suhartiningsih ${ }^{2}$, dan Annisa Mulia Anasis ${ }^{3}$ \\ 1 Jurusan Analis Kesehatan, Poltekkes Kemenkes Mataram \\ ${ }^{2}$ Laboratorium Kesehatan Daerah Provinsi DKI Jakarta \\ ${ }^{3}$ Program Studi Farmasi, Fakultas MIPA, Universitas Tulang Bawang \\ *E-mail: khusumaari@gmail.com
}

\begin{abstract}
Abstrak
Hipertensi adalah keadaan seseorang dengan peningkatan tekanan darah di atas normal. Data pra-survei menunjukkan angka kejadian hipertensi di Kota Metro tahun 2017 mencapai 1.839 kasus dan di Puskesmas Metro Pusat mencapai 481 kasus. Hipertensi berkaitan dengan resiko penyakit kardiovaskuler. Upaya menurunkan tekanan darah penderita hipertensi dengan mengkonsumsi buah yang tinggi kalium seperti belimbing manis. Tujuan penelitian yaitu mengetahui efektifitas belimbing manis (Averrhoa carambola Linn) sebagai anti hipertensi. Desain penelitian pre-experiment designs rancangan one group pre-test post-test. Sampel sebanyak 23 orang menggunakan teknik purposive sampling sesuai kriteria inklusi ekslusi. Analisis univariat pre-post intervensi \& analisis bivariat menggunakan uji paired $t$-test. Hasil uji statistik rerata tekanan darah penderita hipertensi pre-test 149,65/94,87 mmHg dan post-test pemberian belimbing manis 139,61/89,52 $\mathrm{mmHg}$. Hasil analisis paired sample t-test didapatkan $p$-value $0,00<\alpha 0,05$. Belimbing manis efektif sebagai anti hipertensi dengan rerata tekanan darah setelah diberi perlakuan lebih rendah secara bermakna dibandingkan sebelum diberi perlakuan.
\end{abstract}

Kata kunci: hipertensi, kalium, belimbing manis (Averrhoa carambola Linn).

\section{PENDAHULUAN}

Hipertensi atau penyakit darah tinggi adalah keadaan seseorang mengalami peningkatan tekanan darah di atas normal yang ditunjukkan oleh angka sistolik dan angka diastolik pada pemeriksaan tensi darah menggunakan alat pengukur tekanan darah (Kemenkes RI, 2015). Hampir semua orang dengan gagal jantung didahului oleh hipertensi. Jika hipertensi dibiarkan tanpa pengobatan, hampir separuh klien hipertensi akan meninggal karena penyakit jantung dan sisanya $10-15 \%$ akan meninggal karena gagal ginjal (Black \& Hawks, 2014)

Menurut World Health Organization (WHO), saat ini penderita hipertensi di dunia mencapai sekitar 970 juta penderita, sekitar 330 juta terdapat di negara maju dan 640 terdapat di negara berkembang. Di Amerika Serikat hipertensi merupakan diagnosa primer yang umum karena menyerang hampir 50 juta penduduk dimana sekitar $69 \%$ orang dewasa yang telah melewati 18 tahun sadar akan hipertensi yang mereka derita dan 58\% dari mereka dirawat, tetapi hanya $31 \%$ yang terkontrol. Prevalensi hipertensi di benua Amerika lebih rendah dibandingkan di benua Eropa, dimana prevalensi hipertensi di Amerika Serikat 20,3\% dan Kanada 21,4\% sedangkan di beberapa Negara Eropa seperti Swedia 38,4\%, Italia 37,7\%, Inggris 29,6\%, Spanyol $40 \%$ dan Jerman $55,3 \%$ (World Health Organization, 2018).

Prevalensi hipertensi secara nasional terjadi peningkatan yaitu dari 7,6 persen pada tahun 2007 menjadi 9,5 persen pada tahun 2013. Provinsi dengan prevalensi hipertensi pada umur $\geq 18$ tahun berdasarkan wawancara yang tertinggi pada tahun 2013 ialah Provinsi Sulawesi Utara (15,2\%), kemudian disusul Provinsi Kalimantan Selatan (13,3\%), dan DI Yogyakarta (12,9\%o). Sedangkan prevalensi terendah terdapat di Provinsi Papua (3,3\%), kemudian disusul oleh Papua Barat $(5,2 \%)$, 
dan Riau (6,1\%). Kenaikan prevalensi tertinggi terdapat di Provinsi Sulawesi Barat, yakni dari 4,7\% pada tahun 2007 menjadi $9,6 \%$ pada 2013. Sedangkan penurunan prevalensi terbanyak terdapat di Provinsi Riau, yaitu dari $8,2 \%$ pada 2007 menjadi $6,1 \%$ pada 2013. Sedangkan prevalensi hipertensi yang terjadi di Provinsi Lampung pada tahun 2007 adalah sebesar 5,2\% dan pada tahun 2013 meningkat menjadi 7,4\% (Badan Penelitian dan Pengembangan Kesehatan, 2013)

Berdasarkan data yang tercatat di Kasie Surveilans \& Epidemiologi Dinas Kesehatan Kota Metro menunjukkan bahwa jumlah kasus lama hipertensi mencapai 8.268 sedangkan pada laporan terakhir 2017 jumlah kasus baru hipertensi ditemukan sebanyak 1.839 kasus yang tersebar di 11 (sebelas) Puskemas meliputi Puskesmas Mulyojati 189 kasus (10,3\%), Metro 481 kasus (26,2\%), Sumbersari Bantul 75 kasus (4,1\%), Ganjar Agung 163 kasus (88,9\%), Banjarsari 119 kasus (6,5\%), Iringmulyo 100 kasus (5,4\%), Yosomulyo 241 kasus (13,1\%), Karangrejo 76 kasus (4,1\%), Purwosari 76 kasus (4,1\%), Yosodadi 178 kasus (10,0\%) dan Tejoagung 135 kasus (7,3\%) (Dinas Kesehatan Kota Metro, 2018).

Tekanan darah tinggi apabila tidak ditanggulangi maka dalam jangka waktu panjang akan berdampak pada kerusakan arteri di dalam tubuh sampai organ yang mendapat suplai darah dari arteri tersebut. Komplikasi hipertensi diantaranya dapat menyebabkan terjadinya gagal jantung dan penyakit jantung koroner. Komplikasi hipertensi otak dapat menimbulkan risiko stroke. Selain itu, peningkatan tekanan darah dapat menyebabkan terjadinya kerusakan ginjal serta dapat mengakibatkan terjadinya retinopati dan dapat menimbulkan kebutaan (Devicaesaria, 2014)

Penderita hipertensi dengan tekanan darah yang tinggi akan menjalani hidup dengan bergantung pada obat-obatan farmakologi dan kunjungan teratur ke dokter untuk mendapatkan resep ulang dan check-up. Data WHO melaporkan dari 50\% penderita hipertensi yang diketahui hanya $25 \%$ yang mendapat pengobatan, dan hanya $12,5 \%$ yang diobati dengan baik (adequately treated cases). Penggunaan obat-obatan hipertensi juga sering menimbulkan efek samping yang tidak diinginkan yang merupakan hal yang harus dihindari oleh penderita hipertensi. Salah satu contoh efek samping yang umum terjadi adalah meningkatnya kadar gula dan kolesterol, kelelahan serta kehilangan energi. Tidak sedikit penderita yang harus mengkonsumsi obat lain untuk menghilangkan efek samping dari pengobatan hipertensinya. Satu-satunya cara yang dapat dilakukan untuk menghindari efek samping tersebut adalah dengan menghentikan terapi pengobatan farmakologis. Hal inilah yang membuat pasien tidak patuh terhadap terapi pengobatan dan beralih mencari terapi yang lain. Salah satu terapi yang baik dan aman bagi penderita hipertensi adalah melalui terapi non-farmakologis berupa terapi nutrisi yang dilakukan dengan manajemen diet hipertensi, seperti dengan pembatasan konsumsi garam, mempertahankan asupan kalium, kalsium, dan magnesium serta membatasi asupan kalori jika berat badan meningkat. DASH (Dietary Approaches to Stop Hypertension) merekomendasikan pasien hipertensi banyak mengkonsumsi buah-buahan dan sayuran, meningkatkan konsumsi serat, dan minum banyak air (Triyanto, 2014)

Terapi diet merupakan terapi pilihan yang baik untuk penderita hipertensi yaitu dengan cara mengkonsumsi buah-buahan yang dapat mempengaruhi tekanan darah, seperti belimbing manis (Averrhoa carambola Linn). Buah belimbing manis merupakan buah yang sudah dikenal luas oleh masyarakat Indonesia dan mudah ditemukan dengan harganya relatif terjangkau. Buah belimbing manis bermanfaat dalam membantu menurunkan tekanan darah karena kandungan serat, kalium, fosfor, dan vitamin C (Berawi \& Pasya, 2016)

Kandungan air, magnesium dan kalium serta serat yang tinggi pada buah belimbing manis bisa menetralisasi dan menurunkan tekanan darah. Kadar kalium dalam 1 buah belimbing ukuran sedang (127 gram) memiliki kandungan kalium mencapai $207 \mathrm{mg}$ dan serat 3 gram yang mampu menyerap lemak sehingga ikut membantu menurunkan tekanan darah (Anwar, 2014)

Penelitian yang dilakukan oleh Ardiyanto \& Supriyono (2014) menunjukkan bahwa pada hasil studi eksperimen terhadap 21 penderita hipertensi membuktikan bahwa buah belimbing manis terbukti berpengaruh terhadap penurunan tekanan darah sistolik ( $p$-value 0,000$)$ dan diastolik ( $p$ value 0,000 ) (Ardiyanto, Nuraeni, \& Supriyono, 2014). Penelitian lainnya menunjukkan bahwa rata- 
rata tekanan darah sistolik sebelum pemberian jus belimbing adalah $172,24 \mathrm{mmHg}$ dan setelah pemberian menurun menjadi 166,6 $\mathrm{mmHg}$, pada hasil analisis uji t test didapatkan $p$-value 0,000 artinya pemberian jus belimbing berpengaruh terhadap penurunan tekanan darah sistolik. Pada tekanan darah diastolik juga terbukti mengalami penurunan signifikan yaitu sebelum perlakuan 102,2 $\mathrm{mmHg}$ dan setelah perlakuan menurun menjadi $97,67 \mathrm{mmHg}$ dengan nilai signifikansi sebesar $\mathrm{p}$ value 0,000.(Elliya, Hermawan, \& Trismiana, 2016). Berdasarkan penjelasan yang telah dikemukakan, maka peneliti sangat tertarik untuk meneliti tentang efektifitas belimbing manis (Averrhoa carambola Linn) sebagai anti hipertensi.

\section{METODE/EKSPERIMEN}

Jenis penelitian kuantitatif menggunakan desain pre-experiment designs) dengan rancangan one group pretest posttest. Populasi dalam penelitian ini adalah pasien baru penderita hipertensi di Puskesmas Metro Pusat sebanyak 481 orang. Sampel yang digunakan sebanyak 23 orang dengan teknik purposive sampling. Teknik yang didasarkan pada suatu pertimbangan tertentu yang dibuat oleh peneliti sendiri, berdasarkan ciri atau sifat-sifat populasi yang sudah diketahui sebelumnya sesuai dengan kriteria inklusi salah satunya adalah penderita hipertensi primer dengan tekanan darah $>140 / 90 \mathrm{mmHg}$ dan eklusi apabila sampel mengkonsumsi obat anti hipertensi dan menderita komplikasi kronik.Prosedur pengumpulan data penelitian dilakukan melalui beberapa tahapan. Sebelum perlakuan dilakukan pengukuran pertama tekanan darah responden dalam bentuk tekanan sistolik/diastolik. Hasil pengukuran pertama adalah data pre-test kemudian responden diberikan terapi jus belimbing manis (Averrhoa carambola Linn) yang dilakukan satu kali setiap hari sesudah makan dalam jangka waktu 1 minggu (7 hari) yang diberikan pada sore hari. Jus belimbing manis (Averrhoa carambola Linn) disediakan oleh peneliti. Pada waktu yang telah disepakati yaitu pada setiap sore hari peneliti mendatangi responden dan memberikan jus belimbing manis ( $\pm 150 \mathrm{gram}$ ) dan memastikan langsung responden menghabiskan jus belimbing manis (Averrhoa carambola Linn) yang diberikan kemudian diberikan terapi jus belimbing manis (Averrhoa carambola Linn) selama 1 minggu, peneliti kemudian melakukan pengukuran kembali (post-test) untuk memperoleh data tentang tekanan sistolik/diastolik. Analisis univariat pre-post intervensi \& analisis bivariat menggunakan menggunakan uji statistik parametrik uji $\mathrm{T}$ berpasangan (Paired $T$-test). Analisis ini dilakukan dengan menggunakan program SPSS, uji statistik menggunakan taraf signifikan $p<0,05$.

\section{HASIL DAN PEMBAHASAN}

\section{Hasil Penelitian}

Adapun hasil penelitian disajikan dalam dua analis data berupa analisis univariat dengan menampilkan hasil pengukuran tekanan darah responden dilakukan dalam dua tahapan, yaitu perlakuan pertama sebelum pemberian jus belimbing (pre-test) dan pengukuran kembali setelah satu minggu pemberian just belimbing (post-test).Analis Bivariat digunakan untuk mengetahui pengaruh jus belimbing manis (Averrhoa carambola Linn) terhadap tekanan darah pada penderita hipertensi.

\section{Analisis Univariat}

Tabel 1. Rata-rata Tekanan Darah Penderita Hipertensi Sebelum Perlakuan (Pre-test) 
Ari Khusuma, Suhartiningsih, dan Annisa Mulia Anasis

\begin{tabular}{lcclc}
\hline \multicolumn{1}{c}{ Variabel } & Mean & SD & \multicolumn{1}{c}{ Min-Max } & \multicolumn{1}{c}{ Cl; 95\% } \\
\hline $\begin{array}{l}\text { Tekanan darah sistolik sebelum } \\
\text { perlakuan (pre-test) }\end{array}$ & 149,65 & 4,744 & $140-158$ & $147,60-151,70$ \\
$\begin{array}{l}\text { Tekanan darah diastolik sebelum } \\
\text { perlakuan (pre-test) }\end{array}$ & 94,87 & 2,361 & $90-99$ & $93,35-95,89$ \\
\hline
\end{tabular}

Tabel 1 dijelaskan bahwa sebelum (pre-test) intervensi pemberian jus belimbing manis (Averrhoa carambola Linn) rata-rata tekanan darah responden adalah 149,65/94,87 mmHg dengan standar deviasi 4,744/2,361. Tekanan darah minimum sistolik adalah $140 \mathrm{mmHg}$, maksimum 158 $\mathrm{mmHg}$ dan tekanan diastolik minimum $90 \mathrm{mmHg}$, maksimum $99 \mathrm{mmHg}$. Pada confidence interval 95\% diyakini bahwa rata-rata tekanan darah sistolik penderita hipertensi sebelum pemberian jus belimbing manis (Averrhoa carambola Linn) adalah antara 147,60-151,70 mmHg dan tekanan darah diastolik antara 93,35-95,89 $\mathrm{mmHg}$.

Tabel 2. Rata-rata Tekanan Darah Penderita Hipertensi sesudah perlakuan (Post test)

\begin{tabular}{lcccc}
\hline \multicolumn{1}{c}{ Variabel } & Mean & SD & Min-Max & Cl; 95\% \\
\hline $\begin{array}{l}\text { Tekanan darah sistolik sesudah } \\
\text { perlakuan (post-test) }\end{array}$ & 139,61 & 6,279 & $130-149$ & $136,89-142,32$ \\
$\begin{array}{l}\text { Tekanan darah diastolik sesudah } \\
\text { perlakuan (post-test) }\end{array}$ & 89,52 & 5,615 & $80-98$ & $87,09-91,95$ \\
\hline
\end{tabular}

Tabel 2 dijelaskan bahwa sesudah perlakuan (post-test) rata-rata tekanan darah responden adalah 139,61/89,52 mmHg dengan standar deviasi 6,279/5,615. Tekanan darah minimum sistolik adalah $130 \mathrm{mmHg}$, maksimum $149 \mathrm{mmHg}$ dan tekanan diastolik minimum $80 \mathrm{mmHg}$, maksimum 98 $\mathrm{mmHg}$. Pada confidence interval 95\% diyakini bahwa rata-rata tekanan darah sistolik penderita hipertensi setelah pemberian jus belimbing manis (Averrhoa carambola Linn) adalah antara 136,89$142,32 \mathrm{mmHg}$ dan tekanan darah diastolik antara $87,09-91,95 \mathrm{mmHg}$.

\section{Analisis Bivariat}

Tabel 3. Pengaruh Pemberian Belimbing Manis (Averrhoa carambola Linn) terhadap Penurunan Tekanan Darah pada Penderita Hipertensi

\begin{tabular}{|c|c|c|c|c|c|c|c|}
\hline \multirow{2}{*}{\multicolumn{2}{|c|}{ Variabel }} & \multirow{2}{*}{ Mean } & \multirow{2}{*}{$M D$} & \multirow{2}{*}{$S D$} & \multicolumn{2}{|c|}{ Cl;95\% } & \multirow{2}{*}{$p$-value } \\
\hline & & & & & Lower & Upper & \\
\hline \multirow{2}{*}{$\begin{array}{c}\text { Tekanan } \\
\text { darah sistolik }\end{array}$} & Pretest & 149,65 & \multirow{2}{*}{10,43} & \multirow{2}{*}{3,186} & \multirow{2}{*}{8,667} & \multirow{2}{*}{11,420} & \multirow{2}{*}{0,000} \\
\hline & Posttest & 139,61 & & & & & \\
\hline \multirow{2}{*}{$\begin{array}{c}\text { Tekanan } \\
\text { darah } \\
\text { diastolik }\end{array}$} & Pretest & 94,87 & \multirow{2}{*}{5,348} & \multirow{2}{*}{5,382} & \multirow{2}{*}{3,021} & \multirow{2}{*}{7,675} & \multirow{2}{*}{0,000} \\
\hline & Posttest & 89,52 & & & & & \\
\hline
\end{tabular}

Pada Tabel 3 diketahui bahwa pada hasil analisis dengan menggunakan paired sample t-test diperoleh selisih rata-rata tekanan darah sistolik sebelum dan sesudah perlakuan adalah 10,043 $\mathrm{mmHg}$ dengan standar deviasi $3,186 \mathrm{mmHg}$ dan selisih rata-rata tekanan darah diastolik adalah sebesar 5,348 dengan standar deviasi $5,382 \mathrm{mmHg}$. Pada hasil uji statistik didapatkan nilai signifikansi tekanan darah sistolik dan diastolik sebesar $p$-value $0,000<\alpha 0,05$ maka dapat disimpulkan bahwa terdapat perbedaan rata-rata tekanan darah penderita hipertensi sebelum dan sesudah perlakuan, artinya secara statistik terbukti ada pengaruh jus belimbing manis (Averrhoa carambola Linn) terhadap penurunan tekanan darah pada penderita hipertensi, dimana tekanan darah sesudah diberi jus belimbing manis lebih rendah secara bermakna dibandingkan sebelum pemberian jus belimbing manis. 


\section{Pembahasan}

Rata-rata Tekanan Darah Penderita Hipertensi Sebelum Perlakuan (Pre-test)

Berdasarkan hasil pengolahan data dapat diketahui bahwa sebelum (pre-test) intervensi pemberian jus belimbing manis (Averrhoa carambola Linn) rata-rata tekanan darah responden adalah $149,65 / 94,87 \mathrm{mmHg}$ dengan standar deviasi 4,744/2,361. Tekanan darah minimum sistolik adalah $140 \mathrm{mmHg}$, maksimum $158 \mathrm{mmHg}$ dan tekanan diastolik minimum $90 \mathrm{mmHg}$, maksimum $99 \mathrm{mmHg}$. Pada confidence interval 95\% diyakini bahwa rata-rata tekanan darah sistolik penderita hipertensi sebelum pemberian jus belimbing manis (Averrhoa carambola Linn) adalah antara 147,60-151,70 $\mathrm{mmHg}$ dan tekanan darah diastolik antara 93,35-95,89 $\mathrm{mmHg}$. Dari penelitian ini membuktikan kondisi terakhir penderita sebelum perlakuan dengan menunjukkan tekanan darah tinggi presisten dimana tekanan sistoliknya diatas $140 \mathrm{mmHg}$ dan tekanan diastolic di atas $90 \mathrm{mmHg}$ (Ardiansyah, 2013). Hipertensi dengan kondisi peningkatan tekanan darah secara abnormal dan terus menerus pada beberapa kali pemeriksaan tekanan darah yang disebabkan suatu atau beberapa faktor risiko yang berjalan sebagaimana mestinya dalam mempertahankan tekanan darah secara normal.

Hipertensi dapat didefinisikan sebagai tekanan darah tinggi persisten Penyebab hipertensi sendiri sangat beragam diantaranya stress, kegemukan, merokok, hipernatriumia, retensi air dan garam yang tidak normal, sensitifitas terhadap angiotensin, hiperkolesteroemia, penyakit kelenjar adrenal, penyakit ginjal, toxemia gravidarum, peningkatan tekanan intra cranial, yang disebabkan tumor otak, pengaruh obat tertentu misal obat kontrasepsi, asupan garam yang tinggi, kurang olahraga, genetic, aterosklrerosis, kelainan ginjal, tetapi sebagian tidak diketahui penyebabnya (Berawi \& Pasya, 2016)

Hasil penelitian ini sejalan dengan penelitian sebelumnya terhadap penderita hipertensi di menunjukkan bahwa pada hasil analisis didapatkan rerata tekanan darah responden sebelum pemberian jus belimbing adalah $157,25 / 92,90 \mathrm{mmHg}$ dengan standar deviasi $17,906 / 7,802 \mathrm{mmHg}$ (Elliya et al., 2016)

Berdasarkan uraian tersebut dapat dijelaskan bahwa rata-rata tekanan darah penderita hipertensi pada hasil penelitian ini yaitu $149,65 / 94,87 \mathrm{mmHg}$ atau masuk dalam kategori hipertensi derajat I. Diantara faktor yang dapat mempengaruhi peningkatan tekanan darah pada responden mungkin terkait dengan faktor usia dan jenis kelamin semakin tua umur seseorang maka semakin tinggi tekanan darahnya. Sejalan dengan bertambahnya usia, hampir setiap orang mengalami kenaikan tekanan darah. Penuaan mempengaruhi baroreseptor yang terlibat dalam pengaturan tekanan darah serta kelenturan arteri. Ketika arteri menjadi kurang lentur, tekanan dalam pembuluh darah meningkat (Diyono \& Mulyanti, 2013)

Terkait dengan jenis kelamin hipertensi lebih banyak terjadi pada pria bila terjadi pada usia dewasa muda. Tetapi lebih banyak menyerang wanita setelah umur 55 tahun, sekitar $60 \%$ penderita hipertensi adalah wanita. Hal ini sering dikaitakan dengan perubahan hormon setelah menopause. Tekanan darah tinggi apabila tidak diobati dan ditanggulangi maka dalam jangka panjang akan menyebabkan kerusakan arteri dan organ yang mendapat suplai darah arteri tersebut seperti jantung, ginjal, dan otak sehingga memicu terjadinya stroke. Oleh karena itu perlu adanya penatalaksanaan yang tepat, salah satunya menggunakan pengobatan non farmakologi yaitu dengan pemberian buah yang mengandung tinggi kalium seperti buah belimbing manis (Anwar, 2014)

Rata-rata Tekanan Darah Penderita Hipertensi Sesudah Perlakuan (Post-test)

Berdasarkan hasil pengolahan data diketahui bahwa sesudah perlakuan (post-test) rata-rata 
tekanan darah responden adalah 139,61/89,52 $\mathrm{mmHg}$ dengan standar deviasi 6,279/5,615. Tekanan darah minimum sistolik adalah $130 \mathrm{mmHg}$, maksimum $149 \mathrm{mmHg}$ dan tekanan diastolik minimum 80 $\mathrm{mmHg}$, maksimum $98 \mathrm{mmHg}$. Pada confidence interval 95\% diyakini bahwa rata-rata tekanan darah sistolik penderita hipertensi setelah pemberian jus belimbing manis (Averrhoa carambola Linn) adalah antara 136,89-142,32 $\mathrm{mmHg}$ dan tekanan darah diastolik antara 87,09-91,95 mmHg. Dari penelitian ini terlihat bahwa konsumsi jus belimbing memberikan kecenderungan bahwa terjadi penurunan tekanan darah setelah pemberian secara rutin selama satu minggu.

Menurut Berawi (2016), terapi diet merupakan terapi pilihan yang baik untuk penderita hipertensi yaitu dengan cara mengkonsumsi buah-buahan yang dapat mempengaruhi tekanan darah, seperti belimbing manis (Averrhoa carambola Linn). Buah belimbing manis sangat bermanfaat dalam membantu menurunkan tekanan darah karena kandungan serat, kalium, fosfor, dan vitamin C (Berawi \& Pasya, 2016).Kandungan air, magnesium dan kalium serta serat yang tinggi pada buah belimbing manis bisa menetralisasi dan menurunkan tekanan darah. Kadar kalium dalam 1 buah belimbing ukuran sedang (127 gram) memiliki kandungan kalium mencapai $207 \mathrm{mg}$ dan serat 3 gram yang mampu menyerap lemak sehingga ikut membantu menurunkan tekanan darah (Anwar, 2014)

Berdasarkan uraian hasil penelitian diketahuin bahwa setelah dilakukan perlakuan berupa pemberian jus belimbing manis sebanyak \pm 150 gram yang diberikan sebanyak satu kali pada sore hari selama satu minggu, maka didapatkan rata-rata tekanan darah penderita hipertensi lebih rendah dibandingkan dengan sebelum perlakuan. Hal ini menunjukkan bahwa kandungan gizi pada buah belimbing manis memberikan efek terhadap penurunan tekanan darah, dimana salah satu kandungan gizi yang banyak ditemukan dalam jus belimbing manis adalah kalium atau potassium yang sangat penting untuk fungsi tubuh manusia (Ardiyanto et al., 2014)

Pengaruh Buah Belimbing Manis (Averrhoa carambola Linn) Terhadap Penurunan Tekanan Darah pada Penderita Hipertensi

Pengujian hipotesis menggunakan uji paired sample $t$-test diperoleh diperoleh selisih rata-rata tekanan darah sistolik antara sebelum dan sesudah perlakuan adalah $10,043 \mathrm{mmHg}$ dengan standar deviasi $3,186 \mathrm{mmHg}$ dan selisih rata-rata tekanan darah diastolik antara sebelum dan sesudah perlakuan adalah sebesar 5,348 dengan standar deviasi $5,382 \mathrm{mmHg}$. Pada hasil uji statistik didapatkan nilai signifikansi tekanan darah sistolik dan diastolik sebesar $p$-value $0,000<\alpha 0,05$ maka dapat disimpulkan bahwa terdapat perbedaan rata-rata tekanan darah penderita hipertensi sebelum dan sesudah perlakuan, artinya secara statistik terbukti ada pengaruh jus belimbing manis (Averrhoa carambola Linn) terhadap penurunan tekanan darah pada penderita hipertensi, dimana tekanan darah sesudah pemberian belimbing manis lebih rendah secara bermakna dibandingkan sebelum pemberian jus belimbing manis.

Hal ini dapat terjadi karena sebelum diberi perlakuan umumnya penderita hipertensi tidak teratur dalam mempertahankan asupan diet tinggi buah sehingga tekanan darah tidak dapat terkontrol secara baik. Sedangkan selama dilakukan perlakuan, penderita hipertensi secara teratur mempertahankan asupan diet jus belimbing manis yang mengandung tinggi kalium, dimana kalium sendiri merupakan minieral yang memegang peranan penting dalam pemeliharaan keseimbangan cairan dan elektrolit serta keseimbangan asam basa. Kalium yang banyak terdapat pada buah belimbing manis (Averrhoa carambola Linn) dapat menurunkan tekanan darah dengan menimbulkan efek vasodilatasi sehingga menyebabkan penurunan retensi perifer total dan meningkatkan output jantung. Konsumsi kalium yang banyak akan meningkatkan konsentrasinya di dalam cairan intraseluler sehingga cenderung menarik cairan dari bagian ekstraseluler dan menurunkan tekanan darah (Febriani \& Zulfah, 2016).

Di dalam sel, kalsium berfungsi sebagai katalisator dalam banyak reaksi biologik, terutama dalam metabolisme energi dan sintesis glikogen dan protein. Kalium membantu menyeimbangkan 
tekanan darah dan diperlukan untuk reaksi enzim, serta metabolisme karbohidrat dan protein. Kalium membantu pengeluaran racun melalui ginjal, bekerja sama dengan fosfor untuk mengirim oksigen ke otak. Akibat kekurangan kalium dapat menyebabkan henti jantung, hipertensi, menurunnya fungsi hormon adrenal, dan otot kehilangan fungsi kontraksinya (Berawi \& Pasya, 2016).

Hasil penelitian ini sejalan dengan penelitian yang dilakukan oleh Ardiyanto, Nuraeni \& Supriyono (2014) yang dilaksanakan selama satu minggu dengan pemberian jus belimbing satu hari satu kali menunjukkan bahwa pada hasil uji Wilcoxon terbukti bahwa pemberian jus belimbimbing manis berpengaruh terhadap penurunan tekanan darah hipertensi ( $p$-value 0.000) (Ardiyanto et al., 2014).

Penggunaan buah belimbing manis untuk diolah sebagai jus bagi para penderita hipertensi dapat menjadi alternatif selain konsumsi obat-obatan. Tentu saja hal ini didukung dengan pola konsumsi yang teratur dengan proses pengolahan yang tepat sesuai dengan anjuran dokter atau praktisi kesehatan lainnya. Dari sisi ekonomis, buah belimbing manis merupakan buah yang sudah dikenal luas oleh masyarakat Indonesia dan mudah ditemukan dengan harganya relatif terjangkau. Dari penelitian ini diketahui bahwa buah belimbing manis (Averrhoa carambola Linn) efektif sebagai anti hipertensi

\section{PENUTUP}

Berdasarkan hasil penelitian maka dapat diambil kesimpulan sebagai bahwa Distribusi karakteristik penderita hipertensi sebagian besar berusia antara 40 sampai dengan $>50$ tahun $(43,5 \%)$, jenis kelamin laki-laki $(56,5 \%)$. Rata-rata tekanan darah penderita hipertensi sebelum (pretest) pemberian jus belimbing manis (Averrhoa carambola Linn) adalah 149,65/94,87 mmHg. Ratarata tekanan darah penderita hipertensi setelah (posttest) pemberian jus belimbing manis (Averrhoa carambola Linn) adalah 139,61/89,52 mmHg. Belimbing manis (Averrhoa carambola Linn) efektif sebagai anti hipertensi dengan rata-rata tekanan darah penderita hipertensi setelah diberi perlakuan lebih rendah secara bermakna dibandingkan sebelum diberi perlakuan.

\section{UCAPAN TERIMAKASIH}

Ucapan terimakasih ditujukan kepada Ibu Annisa Agata, S.Si, M.Si yang telah membantu dan berkontibusi dalam peneltian ini.

\section{DAFTAR PUSTAKA}

Anwar, R. (2014). Konsumsi buah dan sayur serta konsumsi susu sebagai faktor risiko terjadinya hipertensi di Puskesmas S. Parman Kota Banjarmasin. Jurnal Skala Kesehatan.

Ardiansyah, M. (2013). Keperawatan Medikal Bedah untuk Mahasiswa. International Journal of Soil Science. https://doi.org/10.3923/ijss.2017.32.38

Ardiyanto, I., Nuraeni, A., \& Supriyono, M. (2014). Efektifitas Jus Belimbing Terhadap Penurunan Tekanan Darah Pada Lansia Di Kelurahan Tawangmas Baru Kecamatan Semarang Barat. Jurnal IImi Keperawatan Dan Kebidanan (JIKK).

Badan Penelitian dan Pengembangan Kesehatan. (2013). Riset Kesehatan Dasar 2013. Riset Kesehatan Dasar 2013.

Berawi, K. N., \& Pasya, A. V. (2016). Pengaruh Pemberian Jus Belimbing Manis ( Averrhoacarambola L ) untuk Menurunkan Tekanan Darah. Majority. 
Black, J. m, \& Hawks, J. H. (2014). Keperawatan medika bedah: Manajemen klinis untuk hasil yang diharapkan. 3.

Devicaesaria, A. (2014). Hipertensi Krisis. Medicinus.

Dinas Kesehatan Kota Metro. (2018). Profil Kesehatan Kota Metro 2017. Journal of Chemical Information and Modeling. https://doi.org/10.1017/CBO9781107415324.004

Diyono, \& Mulyanti, S. (2013). Keperawatan Medikal Bedah: Buku Ajar. In Keperawatan Medikal Bedah: Buku Ajar.

Elliya, R., Hermawan, D., \& Trismiana, E. (2016). Pengaruh Jus Mentimun (Cucumis Sativus) Terhadap Penurunan Tekanan Darah Pada Penderita Hipertensi Di Uptd Panti Sosial Lanjut Usia Tresna Werdha Kecamatan Natar Kabupaten Lampung Selatan Tahun 2015. Holistik Jurnal Kesehatan. https://doi.org/10.33024/HJK.V10l1.229

Febriani, E., \& Zulfah, S. (2016). Perbedaan Pengaruh Pemberian Jus Tomat Dengan Jus Belimbing Manis Terhadap Tekanan Darah Pada Penderita Hipertensi. AcTion: Aceh Nutrition Journal. https://doi.org/10.30867/action.v1i1.2

Kemenkes RI. (2015). Hipertensi . The Silent Killer. Pusdatin.

Triyanto, E. (2014). Pelayanan Keperawatan bagi penderita Hipertensi Secara Terpadu. Jurnal Kesehatan Medika Santika.

World Health Organization. (2018). WHO | Blood Pressure. WHO. 